\title{
Production of Electrospun Nanofibers from Food Proteins and Polysaccharides and Their Applications in Food and Drug Sciences
}

\author{
Masoud Aman Mohammadi ${ }^{1}$, Mohammad Reza Rostami ${ }^{1}$, Mojtaba Raeisi ${ }^{2}$, Mahnaz Tabibi Azar ${ }^{* 3}$ \\ 1. Department of Food Science and Technology, Faculty of Nutrition and Food Science, Tabriz University of Medical \\ Sciences, Tabriz, Iran \\ 2. Cereal Health Research Center, Golestan University of Medical Sciences, Gorgan, Iran \\ 3. Department of Food Science and Technology, Faculty of Nutrition and Food Science, Tabriz University of Medical \\ Sciences, Tabriz, Iran
}

Article Type:

Review Article

Article History:

Received: 23 Jul 2018

Revised: 02 Sep 2018

Accepted: 01 Dec 2018

\section{*Correspondence:}

Mahnaz Tabibi Azar, Department of Food Science and Technology, Faculty of Nutrition and Food Science, Tabriz University of Medical Sciences, Tabriz, Iran

mahnaz tabibiazar@yahoo .com

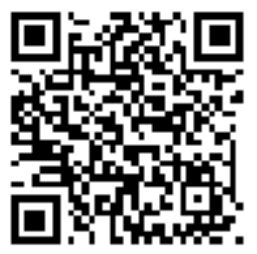

\begin{abstract}
Preparation of nano-microfibers from biopolymers (e.g., proteins and polysaccharides) by using electrospinning technology has been considered by researchers due to the formation of fibers or particles at the nano and micrometer scales, high porosity level, adjustable dewatering behavior, and special mechanical behavior. These products can be used in the microencapsulation of bioactive compounds, stabilization of enzymes and smart packaging. In the electrospinning method, a high voltage is used to create a nanofibers-particles. When the electric field overcomes the surface tension of the droplet, a jet exits the polymeric solution and is formed along the collector surface as it stretches toward the collector panel of the nanofiber. Parameters including molecular weight and polymer microstructure characteristics such as electrical conductivity, viscosity, surface tension, and the electrical potential applied by the device, solution flow rate, distance between the tip of the needle and the collector plate and sometimes the material of the collector plate are effective in the formation of electrospun fibers and particles. In this review, we discussed and evaluated the production stages, the strengths and weaknesses of the fibers produced from proteins and polysaccharides, and their functional properties and potentials, especially in food and drug sciences.
\end{abstract}

Keywords: Electrospinning, Nanofiber, Biopolymers

Copyright $($ 2018, Jorjani Biomedicine Journal has published this work as an open access article under the terms of the Creative Commons Attribution License (http://creativecommons.org/licenses/by-nc/4.0/) which permits noncommercial uses of the work while it is properly cited. 


\section{Introduction}

Electrospinning is an electro hydro dynamic process used to produce nano-microscopic nanoscale fibers, in which the electrical field is applied to a biopolymer solution to produce nanofiber-particle. Electrospinning consists of several simple parts, including a syringe, syringe pump, high voltage source, and collector plate. In this method, the polymer solution is charged under the electric field, and when the repulsive force of unlike charges overcomes the surface tensile force, a jet of polymer particles is guided from the tip of the needle to the collector plate. The jet moves rotationally and the solvent evaporates during the movement, which leads to the formation of the fibers-particles on the surface of the collector plate $(1,2)$. Effective parameters in the electrospinning process are divided into two groups: 1- parameters related to polymer solvent properties (molecular weight, conductivity coefficient, surface tension and viscosity), and 2- parameters related to the process (applied voltage, needle gap to collector plate, solution flow rate, and material of the plate collector) (3).

The properties of the polymeric solution have the most effect on the electrospinning and the fiber structure obtained. The first requirement for the electrospinning process is having a solution with electrospinning capabilities. The diameter of the fiber obtained increases by the elevation of the solution's viscosity. In addition, the increase of the electrical conductivity increases the efficiency of electrospinning. The possibility of involving of the chains and their electrospinning increases by an elevation in the molecular weight. Another important factor affecting the electrospinning process is those applied by the device to the electrospinning current. Considering the applied force resultant, the increase of voltage leads to an increase or decrease of fiber diameter. Increase of the solution current results in increased fiber diameter (4). Owing to their unique features (e.g., high surface-to-volume ratio, high porosity, adjustable dewatering behavior, and mechanical behavior), the fiber obtained by electrospinning can be used in various fields, such as medicine, smart drug delivery, food industry, and tissue engineering (5).

In the electrospinning process, synthetic polymers and biopolymers (proteins and polysaccharides) can be used to produce fibers. The increasing concern of researchers regarding the use of synthetic polymers due to their risks and effects on human health has attracted the attention of scholars to more use of biopolymers. Several biopolymers have been tested for fiber production via electrospinning $(6,7)$. There are many variations in the use of biopolymers in the electrospinning process, in a way that several biopolymers can be used as a combination, which is carried out by applying a solution containing several compounds (8). In studies conducted on a mixture of polymers for electrospinning, multiple systems, and coreshell structures have been significantly considered for food and pharmaceutical applications (9). In the present research, we evaluated the electrospinning of food biopolymers, including proteins and polysaccharides, important parameters involved in their electrospinning, and the main application of these products.

\section{Electrospinning of Protein Fibers}

The presence of the third and fourth structures that prevent their chains from being pulled in 
the form of a chain complicates the electrospinning of proteins. In addition, compared to stranded proteins, spherical proteins have a low ability to be pulled during the electrospinning process due to their significantly low interaction with each other. To increase the electrospinning potential of proteins, they must be completely dissolved in the solvent and their secondary structures must be denatured. While the electrospinning of casein seems easy due to its spiral structure, there is no electrospinning ability in aqueous solutions due to the formation of casein clusters after dissolving in water (10).

As mentioned, proteins must be completely solved in the solvent and denatured in order to have pullability during the electrospinning process (11). With high solubility, solvents can cause the denaturation and electrospinning of proteins by destructing the bonds of the third and fourth structures. The electrospinning of gelatin and collagen can be carried out using solvents such as Hexafluoro2-propanol (HFP) or acidic solutions $(12,13)$. Application of carrier polymer is another method used for electrospinning of proteins. Generally, carrier polymer is a polymer that has electrospinning ability and can give the electrospinning ability to protein by being added to it without the protein having this ability itself. An example of a polymer with a high electrospinning ability is polyvinyl alcohol, which gives the electrospinning ability in combination with soy protein isolate $(14,15)$.

For proteins used in medical applications, polyvinyl alcohol and polyethylene oxide are often selected as carrier polymers $(15,16)$. Another method for electrospinning of proteins is the application of cross linkers, which cause the formation of different properties in the fiber and include natural and synthesis linkers, such as Genipin, glutaraldehyde, N-3-dimethylaminopropyl-nethylcarbodiimide hydrochloride (EDC), and EDC with N-hydroxy sulfo succinimide. Use of crosslinkers in gelatin electrospinning increases the diameter and leads to smearing, ultimately increasing the stability of the produced fibers. Another advantage of using polymer carrier and crosslinkers is the improvement of mechanical stretching and fiber stability $(17,18)$.

There are several crosslinkers that create different features in fibers. The effect of natural and synthetic crosslinkers, such as genipin, glutaraldehyde, N3 dimethylaminopropyl, N-ethylcarbodiimide hydrochloride (EDC), and EDC with Nhydroxysulfosuccinimide (NHS) on collagen electrospinning has been evaluated, demonstrating that EDC and EDC-NHS are the most appropriate choices and establish fiber stability for up to three months (19). However, one of the disadvantages of crosslinkers (e.g., glutaraldehyde) is probably their toxicity. The toxicity of the fibers is due to the inactive compounds remaining in the crosslinkers, which remain in the fibers due to inadequate washing (20). Oleuropein is olive leaf extract that can be used as a natural crosslinker for protein fibers (21).

Protein fibers that are stable in an aqueous environment and without cross linkers, such as laminin fibers produced by Neal et al., are much more than fibers produced by food industry connectors (22). In Table 1, a number of electrospun proteins and solvents used for electrospinning are presented. Subsequently, some of the most important electrospun proteins have been assessed. 
Table 1. Electrospun protein fibers

\begin{tabular}{|c|c|c|}
\hline Protein & Solvent/carrier & References \\
\hline \multirow{5}{*}{ Gelatin } & $\begin{array}{l}\text { poly(caprolactone)/ } \\
\text { hexafluoroisopropanol }\end{array}$ & $\underline{(23)}$ \\
\hline & Acetic acid & $(24)$ \\
\hline & Water & $(25)$ \\
\hline & 2,2,2-Trifluoroethanol & $(26)$ \\
\hline & $\begin{array}{l}\text { Hexafluoro-2- } \\
\text { propanol }\end{array}$ & $\underline{(27)}$ \\
\hline \multirow{4}{*}{ Collagen } & $\begin{array}{l}\text { Acetic acid/Dimethyl } \\
\text { sulfoxide }\end{array}$ & $(28)$ \\
\hline & $\begin{array}{l}\text { Hexafluoro-2- } \\
\text { propanol }\end{array}$ & $(29,30)$ \\
\hline & Trifluoroacetic acid & $(18)$ \\
\hline & $\begin{array}{l}\text { PHBV/ Hexafluoro-2- } \\
\text { propanol }\end{array}$ & $\underline{(31)}$ \\
\hline \multirow[t]{2}{*}{ Soy } & $\begin{array}{l}\text { Polyvinyl } \\
\text { alcohol/water }\end{array}$ & (32) \\
\hline & $\begin{array}{l}\text { polyethylene } \\
\text { oxide/water }\end{array}$ & $(33)$ \\
\hline \multirow{5}{*}{ Zein } & Ethanol & $\begin{array}{ll}(21, & 34, \\
35) & \end{array}$ \\
\hline & Isopropanol & $(36,37)$ \\
\hline & Dimethylformamide & (38) \\
\hline & 2,2,2-Trifluoroethanol & (39) \\
\hline & Acetic acid & $(40)$ \\
\hline \multirow{2}{*}{ Amaranth } & Pullulan/formic acid & $(41,42)$ \\
\hline & $\begin{array}{l}\text { Hexafluoro-2- } \\
\text { propanol }\end{array}$ & $(43)$ \\
\hline \multirow[t]{2}{*}{ Casein } & $\begin{array}{l}\text { polyethylene } \\
\text { oxide/water; } \\
\text { triethanolamine }\end{array}$ & $(44)$ \\
\hline & Pullulan/water & $(45)$ \\
\hline \multirow[t]{2}{*}{ Whey } & Guar gum/water & (8) \\
\hline & $\begin{array}{l}\text { polyethylene } \\
\text { oxide/water }\end{array}$ & $(14,46)$ \\
\hline \multirow[b]{2}{*}{ Algae } & $\begin{array}{l}\text { polyethylene } \\
\text { oxide/water }\end{array}$ & $(47)$ \\
\hline & $\begin{array}{l}\text { poly methylene } \\
\text { oxide/aqueous } \\
\text { sodiumhydroxide }\end{array}$ & $(47)$ \\
\hline $\begin{array}{l}\text { Fish } \\
\text { sarcoplasmic } \\
\text { proteins } \\
\text { (SP) }\end{array}$ & $\begin{array}{l}\text { Hexafluoro-2- } \\
\text { propanol }\end{array}$ & $(48-50)$ \\
\hline
\end{tabular}

\subsection{Soy}

Recognized as one of the most cost-effective protein products, electrospinning isolated soy protein is considered due to its biocompatibility and high maintenance capability (51). In addition, it has features of wound healing and reconstruction of damaged tissues (52). However, this protein cannot perform electrospinning alone and requires a carrier polymer for fiber formation $(53,54)$. Therefore, polyethylene oxide and polyurethane are used as a carrier polymer for electrospinning of isolated soy protein. Isolated soy protein fibers have been applied for microencapsulation of zinc oxide and ciprofloxacin hydrochloride, resulting in positive results such as antimicrobial activity in the laboratory environment (55-57). Moreover, isolated soy protein is employed to package food and produce food foils (53).

\subsection{Gelatin}

Owing to its compatibility with the environment, degradability, and low cost, gelatin, which is obtained from the thermal or chemical degradation of collagen, has been greatly emphasized as a natural polymer. While gelatin is a water-soluble polymer, the electrospinning of its aqueous solution alone is not possible since gel quickly forms and coalesces in the capillary tube during the electrospinning process. The formation of a triple helix depends on the gelatinization of gelatin, which inhibits its electrospinning. Therefore, attention has been paid to the 
combination of solvent and environmental parameters that prevent the formation of this triple helix (58). Researchers have proposed the use of solvents such as formic acid to performing gelatin electrospinning (59). The gelatin/poly caprolactone fibers were produced, and the considerably high level of cell proliferation on the poly caprolactone gelatin scaffolds was shown (60).

\subsection{Zein}

Zein is the major storage protein from corn and a prolamin. In addition, it is a secondary product of bioethanol production in the industry, widely applied to create nano/microfiber since 1960 (61-63). Electrospinning of zein is carried out with food and food industry purposes (64). The loading of curcumin in zein fibers showed that curcumin was released slowly and constantly and revealed anti-oxidant and antibacterial properties. Zine fibers are exploited to improve the oxidative stability of fish oil. When placed in zein fibers, omega 3 fatty acids (Omega 3) are more protected against oxidation, compared to omega- 3 fatty acids that have a free state (65-67).

\subsection{Amaranth}

The amaranth protein isolates have an herbal origin. Along with pullulan, this protein is electrospun for microencapsulation of folic acid (41), curcumin (42), folic acid and quercetin (68). For example, quercetin and folic acid are released in electrolytic fibers continuously and slowly, and their antioxidant properties are more likely to be preserved, compared to the free mode (68).

\subsection{Marine Proteins}

The health providing and bio-activity benefits of fish proteins have made increased their use in various areas, including pharmaceutical and food industry (69-73). Electrospinning of the proteins obtained fromBotryococcus braunii algae was carried out applying polyethylene oxide as a carrier $(69,70)$. In addition, researchers have studied the electrospinning of sarcoplasmic protein (soluble in water), which includes peptides and proteins with high molecular weights. Fish sarcoplasmic protein is economically justifiable due to its abundance in industrial Wastewater. In addition, nano/microfibers produced from fish sarcoplasmic protein cannot be dissolved in an aqueous environment and are decomposed by proteolytic enzymes (74).

\subsection{Whey Protein Isolates}

The whey protein isolate is water soluble and forms more particles when electrospun separately (75). The electrospinning of the protein is carried out with the concomitant use of a carrier, including pullulan (76) and polyethylene oxide (46). Fibers produced by the electrospinning of whey protein isolates are applied for microencapsulation of 
probiotic bacteria to increase their survival (77). In addition, whey protein isolates are exploited for encapsulation of rosemary extract. Evaluation of its release demonstrated that release depends on $\mathrm{pH}$, which argues the possibility of its use in smart drug delivery systems (46). Furthermore, whey protein isolates are electrospun along with dextran and the resulting fibers have acceptable morphology (78). Electrospinning of whey protein isolates along with Guar gum in aqueous solution was carried out, where the major part of the resulting fibers was whey protein isolates (8).

\subsection{Casein}

Casein is an insoluble milk protein, accounting for $70 \%$ of milk proteins (79). However, casein alone cannot be electrospun and must undergo this process along with a carrier such as polyvinyl alcohol, polyethylene oxide, and pullulan. Casein fibers with polyethylene oxide were prepared to stabilize the lipase enzyme, and the activity of the lipase enzyme in polyvinyl alcohol fibers was six times higher than that of casein and polyethylene oxide fibers, which can be attributed to the high level of polyvinyl alcohol fibers, which increases the level of access to the enzyme (44).

\section{Polysaccharide Electrospinning} Polysaccharides are the most abundant renewable resources in the environment. In Table 2, a number of electrospun polysaccharides and solvents used for their electrospinning are presented. The electrospinning capacity of the polysaccharides depends on the length of the molecular chains and the interconnection of the molecular chains to each other during stretching $(6,80)$. Therefore, molecular weight, the concentration of biopolymer solution, their conformation structure and dilution in shear thinning affect their electrospinning properties. The concentration required for the electrospinning of polysaccharides is a concentration in which the polysaccharide molecules become closer to each other so that the molecular bonding of the chain to the adjacent chain could be possible.

This situation is associated with stretching and electrospinning. Polysaccharides with a random spiral structure and a low-shear thinning behavior (e.g., amylose and starch amylopectin) are suitable for electrospinning. In addition, spherical polysaccharides have a lower tendency for electrospinning $(6,81)$. In Table 2, a number of electrospun polysaccharides and solvents used for their electrospinning are presented. In the next part, some of the most important electrospun polysaccharides will be evaluated. 
Table 2. Electrospun polysaccharide

\begin{tabular}{|c|c|c|}
\hline $\begin{array}{l}\text { Polysaccharid } \\
\mathrm{e}\end{array}$ & Solvent & $\begin{array}{l}\text { Referenc } \\
\mathrm{e}\end{array}$ \\
\hline Chitosan & $\begin{array}{l}\text { Trifluoroacetic } \\
\text { acid/Dichloromethan } \\
\text { e } \\
\text { Acetic acid }\end{array}$ & $(82-85)$ \\
\hline Starch & $\begin{array}{l}\text { Formic acid } \\
\text { Dimethyl sulfoxide } \\
95 \%\end{array}$ & $\begin{array}{l}(81,86- \\
88)\end{array}$ \\
\hline Alginate & Pullulan/water & (89) \\
\hline Pullulan & $\begin{array}{l}\text { Redistilled water } \\
\text { Dimethyl sulfoxide } \\
\text { and Dimethyl } \\
\text { sulfoxide/water } \\
\text { 95\% Formic acid }\end{array}$ & $\begin{array}{ll}(81, & 87, \\
88, & 90, \\
91) & \end{array}$ \\
\hline
\end{tabular}

\subsection{Chitosan}

Chitosan is a polysaccharide derived from chitin, which is produced by thermochemical reactions. Chitosan can be found in weak acids such as acetic acid. One of the unique features of chitosan is its antimicrobial property, which is due to the presence of positive charge amine groups in its structure that react with bacterial cell membranes and cause bacterial death through their destruction (92, 93). Several attempts have been made to make electrospun chitosan nanofibers by changing the electrospinning conditions (needle distance to the collector plate, voltage, solvent flow rate), as well as the physical and chemical properties of chitosan, such as the molecular weight $(\mathrm{Mw})$ of chitosan or the change of solvent type (9496). In a study, chitosan fibers were used for microencapsulation of the essential oil. Moreover, the researchers assessed the effect of rheological properties on electrospinning of chitosan (97). Moreover, the electrospun chitosan nanofibers are applied for microencapsulation of glucose oxidase and hydrogen peroxide, which have revealed their antimicrobial properties (98). Essential oils of cinnamon (99), silver particles (100, 101), curcumin (102) and lysosome (103) were electrospun in chitosan fibers.

\subsection{Starch}

Starch is a plant protein storage that consists of two parts, namely amylose and amylopectin. Early studies have focused on the electrospinning potential of amyloid due to the linearity and ability to establish intramolecular bonding $(81,87,88)$. Amylopectin content of starch plays an important role in the electrospinning of starch and should be below $65 \%$ since helix structure of starch increases the electrospinning ability and leads to the formation of starch nanofibers (104). Starch derivatives such as hydroxypropyl are electrospun in combination with polyethylene oxide, and the resulting fibers are used in tissue engineering (105). 


\subsection{Alginate}

In a research, the electrospun nanofiber of alginate was obtained using a polar solid solvent such as glycerol (106). In addition to reporting a diameter of $120-300 \mathrm{~nm}$ for the fiber produced, researchers demonstrated that the fiber diameter had a direct relationship with alginate concentration and the ratio of water and glycerol to the solvent. The presence of glycerol in alginate solutions improves the alginate electrospinning, which is the result of the destruction of intracellular and exogenous hydrogen bonds of alginate chains. To facilitate alginate electrospinning, the combination with other polymers, such as polyethylene oxide, was evaluated (107). Generally, the electrospun alginate/chitosan mixture can be used for the treatment of wounds and drug delivery applications (108). Furthermore, the fibers obtained from alginate-pectin-polyethylene oxide mixture can be exploited for microencapsulation of folic acid to increase its sustainability against the light (109).

\subsection{Cellulose}

Cellulose is insoluble in a wide range of solvents due to its chemical structure (110). The electrospinning process of this polysaccharide is limited, and the electrospinning ability of cellulose significantly depends on molecular weight and solvent selection (111). The cellulosebased electrospun nanofibers have been assessed for non-immobilizing of enzymes and microencapsulation of drug/vitamin (112). The cellulose acetate nanofibers with a $230 \mathrm{~nm}$ diameter are used for nonimmobilizing of Lipase Candida rugose, which showed the significant increase in thermal stability and relatively high durability relative to the equivalent free enzyme (113). In addition, the electrospun cellulose acetate fibers are applied as biosensors to detect the considerably low concentrations of viologen and cytochrome $\mathrm{C}$ in aqueous solutions (114).

\subsection{Dextran}

A bacterial polysaccharide composed of Dglucopyranose units, dextran has several applications in areas of drug delivery, medicine and food industry owing to its biocompatibility and biodegradability features (115). The crosslinking of dextran by glutaraldehyde occurs with regard to the water solubility of dextran, and the resulting fiber with a diameter of $200 \mathrm{~nm}$ can be used in biosensors $(116,117)$.

\subsection{Pullulan}

Pullulan is also water soluble and fibers with a diameter of 100-700 $\mathrm{nm}$ are obtained in their electrospinning from aqueous solution. In addition, this compound is used as a carrier 
polymer $(90,118)$, and its fibers with a diameter of several hundred $\mathrm{nm}$ to several $\mu \mathrm{m}$ were obtained by electrospinning of the solution containing a mixture of $\mathrm{DMSO} /$ water as a solvent. The electrospun fibers can be used for microencapsulation of bioactive compounds and active packaging $(119,120)$. Furthermore, pullulan fibers have been exploited along with amaranth protein for microencapsulation of curcumin and quercetin $(42,68)$.

\section{Conclusion}

Electrospinning is a cost-effective and simple technique for nanofiber production with the use of polymers. Given the high potential of nanofibers in various fields (e.g., medicine, smart drug delivery, active food packaging and filtration) and with regard to the increasing concerns of researchers about the adverse effects of synthetic compounds, the electrospun polymer nanofibers are expected to be produced at industrial scales for application in the mentioned fields, especially as a foundation for antibacterial compounds.

\section{Acknowledgments}

This article was approved as a research project with the code of 964459 and was financially supported by the National Institute for Medical Research Development.

\section{Declarations}

\section{Conflict of interest}

We declare that we have no financial or non-financial conflicts of interest related to the subject matter or materials discussed in the article.

\section{Authors' contributions}

All authors contributed equally to this work.

\section{References}

1. Jacobsen C, Garcia-Moreno PJ, Mendes AC, Mateiu RV, Chronakis IS. Use of Electrospinning for Encapsulation of Sensitive Bioactive Compounds and Applications in Food. Annual review of food science and technology. 2018;9(1).

2. Haider A, Haider S, Kang I-K. A comprehensive review summarizing the effect of electrospinning parameters and potential applications of nanofibers in biomedical and biotechnology. Arabian Journal of Chemistry. 2018;11(8):1165-88.

3. Greiner A, Wendorff JH. Electrospinning: a fascinating method for the preparation of ultrathin fibers. Angewandte Chemie International Edition. 2007;46(30):5670-703.

4. Ghorani B, Tucker N. Fundamentals of electrospinning as a novel delivery vehicle for bioactive compounds in food nanotechnology. Food Hydrocolloids. 2015;51:227-40.

5. Schiffman JD, Schauer CL. A review: electrospinning of biopolymer nanofibers and their applications. Polymer reviews. 2008;48(2):317-52.

6. Stijnman AC, Bodnar I, Tromp RH. Electrospinning of food-grade polysaccharides. Food Hydrocolloids. 2011;25(5):1393-8.

7. Wongsasulak S, Patapeejumruswong M, Weiss J, Supaphol P, Yoovidhya T. Electrospinning of food-grade nanofibers from cellulose acetate and egg albumen blends. Journal of Food Engineering. 2010;98(3):370-6. 
8. Ramazani S, Rostami M, Raeisi M, Tabibiazar M, Ghorbani M. Fabrication of foodgrade nanofibers of whey protein Isolate-Guar gum using the electrospinning method. Food Hydrocolloids. 2019;90:99-104.

9. Alharbi HF, Luqman M, Khalil KA, Elnakady YA, Abd-Elkader OH, Rady AM, et al. Fabrication of core-shell structured nanofibers of poly (lactic acid) and poly (vinyl alcohol) by coaxial electrospinning for tissue engineering. European Polymer Journal. 2018;98:483-91.

10. Pitkowski A, Durand D, Nicolai T. Structure and dynamical mechanical properties of suspensions of sodium caseinate. Journal of Colloid and Interface Science. 2008;326(1):96102.

11. Bhardwaj N, Kundu SC. Electrospinning: a fascinating fiber fabrication technique. Biotechnology advances. 2010;28(3):325-47.

12. Piccirillo G, Ditaranto MV, Feuerer NF, Berrio DAC, Brauchle EM, Pepe A, et al. Noninvasive characterization of hybrid gelatin: poly-1lactide electrospun scaffolds using second harmonic generation and multiphoton imaging. Journal of Materials Chemistry B. 2018;6(40):6399-412.

13. Middleton R, Li X, Shepherd J, Li Z, Wang W, Best SM, et al. Near-Field Electrospinning Patterning Polycaprolactone and Polycaprolactone/Collagen Interconnected Fiber Membrane. Macromolecular Materials and Engineering. 2018;303(2):1700463.

14. Sullivan ST, Tang C, Kennedy A, Talwar S, Khan SA. Electrospinning and heat treatment of whey protein nanofibers. Food Hydrocolloids. 2014;35:36-50.

15. Adeli H, Khorasani MT, Parvazinia M. Wound dressing based on electrospun PVA/chitosan/starch nanofibrous mats: Fabrication, antibacterial and cytocompatibility evaluation and in vitro healing assay. International journal of biological macromolecules. 2019;122:238-54.

16. Kuntzler SG, Costa JAV, de Morais MG. Development of electrospun nanofibers containing chitosan/PEO blend and phenolic compounds with antibacterial activity. International journal of biological macromolecules. 2018.

17. Gomes S, Rodrigues G, Martins G, Roberto $M$, Mafra $M$, Henriques $C$, et al. In vitro and in vivo evaluation of electrospun nanofibers of PCL, chitosan and gelatin: a comparative study. Materials Science and Engineering: C. 2015;46:348-58.

18. Huang GP, Shanmugasundaram S, Masih P, Pandya D, Amara S, Collins $G$, et al. An investigation of common crosslinking agents on the stability of electrospun collagen scaffolds. Journal of Biomedical Materials Research Part A. 2015;103(2):762-71.

19. Torres-Giner S, Ocio MJ, Lagaron JM. Novel antimicrobial ultrathin structures of zein/chitosan blends obtained by electrospinning. Carbohydrate Polymers. 2009;77(2):261-6.

20. Zhang Y, Venugopal J, Huang Z-M, Lim C, Ramakrishna S. Crosslinking of the electrospun gelatin nanofibers. Polymer. 2006;47(8):2911-7.

21. Erdogan I, Demir M, Bayraktar O. Olive leaf extract as a crosslinking agent for the preparation of electrospun zein fibers. Journal of Applied Polymer Science. 2015;132(4).

22. Neal RA, McClugage III SG, Link MC, Sefcik LS, Ogle RC, Botchwey EA. Laminin nanofiber meshes that mimic morphological properties and bioactivity of basement membranes. Tissue Engineering Part C: Methods. 2008;15(1):11-21.

23. Rahmani S, Tabandeh F, Faghihi S, Amoabediny G, Shakibaie M, Noorani B, et al. Fabrication and characterization of poly ( $\varepsilon$ caprolactone)/gelatin nanofibrous scaffolds for retinal tissue engineering. International Journal of Polymeric Materials and Polymeric Biomaterials. 2018;67(1):27-35.

24. Mahmood K, Kamilah H, Sudesh K, Karim AA, Ariffin F. Study of electrospun fish gelatin nanofilms from benign organic acids as solvents. Food Packaging and Shelf Life. 2019; 19:66-75. 
25. Kwak HW, Shin M, Lee JY, Yun H, Song DW, Yang Y, et al. Fabrication of an ultrafine fish gelatin nanofibrous web from an aqueous solution by electrospinning. International journal of biological macromolecules. 2017;102:1092-103.

26. Son SR, Franco RA, Bae SH, Min YK, Lee BT. Electrospun PLGA/gelatin fibrous tubes for the application of biodegradable intestinal stent in rat model. Journal of Biomedical Materials Research Part B: Applied Biomaterials. 2013;101(6):1095-105.

27. Ramanathan G, Singaravelu S, Raja M, Nagiah N, Padmapriya P, Ruban K, et al. Fabrication and characterization of a collagen coated electrospun poly (3-hydroxybutyric acid)gelatin nanofibrous scaffold as a soft bio-mimetic material for skin tissue engineering applications. RSC Advances. 2016;6(10):7914-22.

28. Elamparithi A, Punnoose AM, Kuruvilla S. Electrospun type 1 collagen matrices preserving native ultrastructure using benign binary solvent for cardiac tissue engineering. Artificial cells, nanomedicine, and biotechnology. 2016;44(5):1318-25.

29. Liu S-J, Kau Y-C, Chou C-Y, Chen J-K, $\mathrm{Wu}$ R-C, Yeh W-L. Electrospun PLGA/collagen nanofibrous membrane as early-stage wound dressing. Journal of Membrane Science. 2010;355(1-2):53-9.

30. Rath G, Hussain T, Chauhan G, Garg T, Goyal AK. Collagen nanofiber containing silver nanoparticles for improved wound-healing applications. Journal of drug targeting. 2016;24(6):520-9.

31. Wang Y, Zhang W, Yuan J, Shen J. Differences in cytocompatibility between collagen, gelatin and keratin. Materials Science and Engineering: C. 2016;59:30-4.

32. Fang Q, Zhu M, Yu S, Sui G, Yang X. Studies on soy protein isolate/polyvinyl alcohol hybrid nanofiber membranes as multi-functional eco-friendly filtration materials. Materials Science and Engineering: B. 2016;214:1-10.

33. Ramji K, Shah RN. Electrospun soy protein nanofiber scaffolds for tissue regeneration. Journal of biomaterials applications. 2014;29(3):411-22.
34. Aytac Z, Ipek S, Durgun E, Uyar T. Antioxidant electrospun zein nanofibrous web encapsulating quercetin/cyclodextrin inclusion complex. Journal of Materials Science. 2018;53(2):1527-39.

35. Altan A, Aytac Z, Uyar T. Carvacrol loaded electrospun fibrous films from zein and poly (lactic acid) for active food packaging. Food Hydrocolloids. 2018;81:48-59.

36. Moomand K, Lim L-T. Oxidative stability of encapsulated fish oil in electrospun zein fibres. Food research international. 2014;62:523-32.

37. Moomand K, Lim L-T. Properties of encapsulated fish oil in electrospun zein fibres under simulated in vitro conditions. Food and bioprocess technology. 2015;8(2):431-44.

38. Aytac Z, Ipek S, Durgun E, Tekinay T, Uyar T. Antibacterial electrospun zein nanofibrous web encapsulating thymol/cyclodextrin-inclusion complex for food packaging. Food chemistry. 2017;233:117-24.

39. Alhusein N, Blagbrough IS, Beeton ML, Bolhuis A, Paul A. Electrospun zein/PCL fibrous matrices release tetracycline in a controlled manner, killing Staphylococcus aureus both in biofilms and ex vivo on pig skin, and are compatible with human skin cells. Pharmaceutical research. 2016;33(1):237-46.

40. Vogt L, Liverani L, Roether JA, Boccaccini AR. Electrospun Zein Fibers Incorporating Poly (glycerol sebacate) for Soft Tissue Engineering. Nanomaterials. 2018;8(3):150.

41. Aceituno-Medina M, Mendoza S, Lagaron JM, López-Rubio A. Photoprotection of folic acid upon encapsulation in food-grade amaranth (Amaranthus hypochondriacus L.) protein isolate-Pullulan electrospun fibers. LWTFood Science and Technology. 2015;62(2):970-5.

42. Blanco-Padilla A, López-Rubio A, Loarca-Piña G, Gómez-Mascaraque LG, Mendoza S. Characterization, release and antioxidant activity of curcumin-loaded amaranth-pullulan electrospun fibers. LWT-Food Science and Technology. 2015;63(2):1137-44.

43. Aceituno-Medina M, Mendoza S, Lagaron JM, López-Rubio A. Development and characterization of food-grade electrospun fibers 
from amaranth protein and pullulan blends. Food research international. 2013;54(1):667-74.

44. Xie J, Hsieh Y-L. Ultra-high surface fibrous membranes from electrospinning of natural proteins: casein and lipase enzyme. Journal of Materials Science. 2003;38(10):212533.

45. Tomasula P, Sousa A, Liou S-C, Li R, Bonnaillie L, Liu L. Electrospinning of casein/pullulan blends for food-grade applications. Journal of dairy science. 2016;99(3):1837-45.

46. Colín-Orozco J, Zapata-Torres $\mathrm{M}$, Rodríguez-Gattorno G, Pedroza-Islas R. Properties of poly (ethylene oxide)/whey protein isolate nanofibers prepared by electrospinning. Food Biophysics. 2015;10(2):134-44.

47. Verdugo M, Lim L-T, Rubilar M. Electrospun protein concentrate fibers from microalgae residual biomass. Journal of Polymers and the Environment. 2014;22(3):373-83.

48. Stephansen K, Chronakis IS, Jessen F. Bioactive electrospun fish sarcoplasmic proteins as a drug delivery system. Colloids and Surfaces B: Biointerfaces. 2014;122:158-65.

49. Stephansen K, García-Díaz M, Jessen F, Chronakis IS, Nielsen HM. Bioactive proteinbased nanofibers interact with intestinal biological components resulting in transepithelial permeation of a therapeutic protein. International journal of pharmaceutics. 2015;495(1):58-66.

50. Stephansen K, García-Díaz M, Jessen F, Chronakis IS, Nielsen HM. Interactions between surfactants in solution and electrospun protein Fibers: Effects on release behavior and fiber properties. Molecular pharmaceutics. 2016;13(3):748-55.

51. Chien KB, Shah RN. Novel soy protein scaffolds for tissue regeneration: material characterization and interaction with human mesenchymal stem cells. Acta biomaterialia. 2012;8(2):694-703.

52. Olami H, Zilberman M. Microstructure and in vitro cellular response to novel soy proteinbased porous structures for tissue regeneration applications. Journal of biomaterials applications. 2016;30(7):1004-15.

53. Aydogdu A, Yildiz E, Ayhan Z, Aydogdu Y, Sumnu G, Sahin S. Nanostructured Poly (lactic acid)/Soy Protein/HPMC films by electrospinning for potential applications in food industry. European Polymer Journal. 2019.

54. Hong H, Tronstad ZC, Yang Y, Green MD. Characterization of PVC-soy protein nonwoven mats prepared by electrospinning. AIChE Journal. 2018;64(7):2737-44.

55. Vega-Lugo A-C, Lim L-T. Electrospinning of soy protein isolate nanofibers. Journal of Biobased Materials and Bioenergy. 2008;2(3):223-30.

56. Wongkanya R, Chuysinuan P, Pengsuk C, Techasakul S, Lirdprapamongkol K, Svasti J, et al. Electrospinning of alginate/soy protein isolated nanofibers and their release characteristics for biomedical applications. Journal of Science: Advanced Materials and Devices. 2017;2(3):30916.

57. Kumar NS, Santhosh C, Sudakaran SV, Deb A, Raghavan V, Venugopal V, et al. Electrospun polyurethane and soy protein nanofibres for wound dressing applications. IET Nanobiotechnology. 2017.

58. Zhan J, Lan P. The review on electrospun gelatin fiber scaffold. Journal of Research Updates in Polymer Science. 2013;1(2):59-71.

59. Ki CS, Baek DH, Gang KD, Lee KH, Um IC, Park YH. Characterization of gelatin nanofiber prepared from gelatin-formic acid solution. Polymer. 2005;46(14):5094-102.

60. Tan RP, Chan AH, Lennartsson K, Miravet MM, Lee BS, Rnjak-Kovacina J, et al. Integration of induced pluripotent stem cellderived endothelial cells with polycaprolactone/gelatin-based electrospun scaffolds for enhanced therapeutic angiogenesis. Stem cell research \& therapy. 2018;9(1):70.

61. Lawton JW. Zein: A history of processing and use. Cereal Chemistry. 2002;79(1):1-18. 
62. Shukla R, Cheryan M. Zein: the industrial protein from corn. Industrial crops and products. 2001;13(3):171-92.

63. Torres-Giner S, Gimenez E, Lagarón JM. Characterization of the morphology and thermal properties of zein prolamine nanostructures obtained by electrospinning. Food Hydrocolloids. 2008;22(4):601-14.

64. Kasaai MR. Zein and zein-based nanomaterials for food and nutrition applications: A review. Trends in Food Science \& Technology. 2018.

65. Wang Y, Chen L. Electrospinning of prolamin proteins in acetic acid: the effects of protein conformation and aggregation in solution. Macromolecular Materials and Engineering. 2012;297(9):902-13.

66. Wang Y, Zhang C-1, Zhang Q, Li P. Composite electrospun nanomembranes of fish scale collagen peptides/chito-oligosaccharides: antibacterial properties and potential for wound dressing. International journal of nanomedicine. 2011;6:667.

67. Wang H, Hao L, Wang P, Chen M, Jiang $\mathrm{S}$, Jiang S. Release kinetics and antibacterial activity of curcumin loaded zein fibers. Food Hydrocolloids. 2017;63:437-46.

68. Aceituno-Medina M, Mendoza S, Rodríguez BA, Lagaron JM, López-Rubio A. Improved antioxidant capacity of quercetin and ferulic acid during in-vitro digestion through encapsulation within food-grade electrospun fibers. Journal of Functional Foods. 2015;12:33241.

69. Ewart HS, Dennis D, Potvin M, Tiller C, Fang L-h, Zhang R, et al. Development of a salmon protein hydrolysate that lowers blood pressure. European Food Research and Technology. 2009;229(4):561-9.

70. Girgih AT, He R, Hasan FM, Udenigwe CC, Gill TA, Aluko RE. Evaluation of the in vitro antioxidant properties of a cod (Gadus morhua) protein hydrolysate and peptide fractions. Food chemistry. 2015;173:652-9.

71. Himaya S, Ngo D-H, Ryu B, Kim S-K. An active peptide purified from gastrointestinal enzyme hydrolysate of Pacific cod skin gelatin attenuates angiotensin-1 converting enzyme
(ACE) activity and cellular oxidative stress. Food Chemistry. 2012;132(4):1872-82.

72. Pilon G, Ruzzin J, Rioux L-E, Lavigne C, White PJ, Frøyland L, et al. Differential effects of various fish proteins in altering body weight, adiposity, inflammatory status, and insulin sensitivity in high-fat-fed rats. Metabolism. 2011;60(8):1122-30.

73. Farvin KS, Andersen LL, Nielsen HH, Jacobsen C, Jakobsen G, Johansson I, et al. Antioxidant activity of Cod (Gadus morhua) protein hydrolysates: In vitro assays and evaluation in 5\% fish oil-in-water emulsion. Food chemistry. 2014;149:326-34.

74. Sett S, Stephansen K, Yarin A. Solutionblown nanofiber mats from fish sarcoplasmic protein. Polymer. 2016;93:78-87.

75. Fabra MJ, López-Rubio A, Lagaron JM. Use of the electrohydrodynamic process to develop active/bioactive bilayer films for food packaging applications. Food Hydrocolloids. 2016;55:11-8.

76. Drosou C, Krokida M, Biliaderis CG. Composite pullulan-whey protein nanofibers made by electrospinning: Impact of process parameters on fiber morphology and physical properties. Food Hydrocolloids. 2017.

77. López-Rubio A, Sanchez E, Wilkanowicz $\mathrm{S}$, Sanz Y, Lagaron JM. Electrospinning as a useful technique for the encapsulation of living bifidobacteria in food hydrocolloids. Food Hydrocolloids. 2012;28(1):159-67.

78. Turan D, Gibis M, Gunes G, Baier SK, Weiss J. The impact of the molecular weight of dextran on formation of whey protein isolate (WPI)-dextran conjugates in fibers produced by needleless electrospinning after annealing. Food $\&$ function. 2018;9(4):2193-200.

79. Ng-Kwai-Hang K, Hayes J, Moxley J, Monardes H. Association of genetic variants of casein and milk serum proteins with milk, fat, and protein production by dairy cattle. Journal of dairy science. 1984;67(4):835-40.

80. Santos C, Silva CJ, Büttel Z, Guimarães R, Pereira SB, Tamagnini $P$, et al. Preparation and characterization of polysaccharides/PVA blend nanofibrous membranes by electrospinning method. Carbohydrate polymers. 2014;99:584-92. 
81. Kong L, Ziegler GR. Fabrication of pure starch fibers by electrospinning. Food Hydrocolloids. 2014;36:20-5.

82. Mendes AC, Stephansen K, Chronakis IS. Electrospinning of food proteins and polysaccharides. Food Hydrocolloids. 2016;30:1e16.

83. Pakravan M, Heuzey M-C, Ajji A. Coreshell structured PEO-chitosan nanofibers by coaxial electrospinning. Biomacromolecules. 2012;13(2):412-21.

84. Sun K, Li Z. Preparations, properties and applications of chitosan based nanofibers fabricated by electrospinning. Express Polymer Letters. 2011;5(4).

85. Sangsanoh P, Suwantong O, Neamnark A, Cheepsunthorn P, Pavasant P, Supaphol P. In vitro biocompatibility of electrospun and solventcast chitosan substrata towards Schwann, osteoblast, keratinocyte and fibroblast cells. European Polymer Journal. 2010;46(3):428-40.

86. Lancuški A, Vasilyev G, Putaux J-L, Zussman E. Rheological properties and electrospinnability of high-amylose starch in formic acid. Biomacromolecules. 2015;16(8):2529-36.

87. Kong L, Ziegler GR. Formation of starchguest inclusion complexes in electrospun starch fibers. Food hydrocolloids. 2014;38:211-9.

88. Kong L, Ziegler GR. Rheological aspects in fabricating pullulan fibers by electro-wetspinning. Food Hydrocolloids. 2014;38:220-6.

89. Xiao Q, Lim L-T. Pullulan-alginate fibers produced using free surface electrospinning. International journal of biological macromolecules. 2018;112:809-17.

90. Sun XB, Jia D, Kang WM, Cheng BW, Li $\mathrm{YB}$, editors. Research on electrospinning process of pullulan nanofibers. Applied Mechanics and Materials; 2013: Trans Tech Publ.

91. Guo C, Zhou L, Lv J. Effects of expandable graphite and modified ammonium polyphosphate on the flame-retardant and mechanical properties of wood flour- polypropylene composites. Polymers \& Polymer Composites. 2013;21(7):449.

92. Sarhan WA, Azzazy HM. High concentration honey chitosan electrospun nanofibers: biocompatibility and antibacterial effects. Carbohydrate polymers. 2015;122:135-43.

93. Nguyen TTT, Chung OH, Park JS. Coaxial electrospun poly (lactic acid)/chitosan (core/shell) composite nanofibers and their antibacterial activity. Carbohydrate Polymers. 2011;86(4):1799-806.

94. Balan V, Verestiuc L. Strategies to improve chitosan hemocompatibility: A review. European Polymer Journal. 2014;53:171-88.

95. Jayakumar R, Menon D, Manzoor K, Nair $\mathrm{S}$, Tamura H. Biomedical applications of chitin and chitosan based nanomaterials-A short review. Carbohydrate Polymers. 2010;82(2):22732.

96. Luo Y, Wang Q. Recent development of chitosan-based polyelectrolyte complexes with natural polysaccharides for drug delivery. International journal of biological macromolecules. 2014;64:353-67.

97. Rieger KA, Birch NP, Schiffman JD. Electrospinning chitosan/poly (ethylene oxide) solutions with essential oils: Correlating solution rheology to nanofiber formation. Carbohydrate polymers. 2016;139:131-8.

98. Bösiger P, Tegl G, Richard IM, Le Gat L, Huber L, Stagl V, et al. Enzyme functionalized electrospun chitosan mats for antimicrobial treatment. Carbohydrate polymers. 2018;181:5519.

99. Wen P, Zhu D-H, Wu H, Zong M-H, Jing Y-R, Han S-Y. Encapsulation of cinnamon essential oil in electrospun nanofibrous film for active food packaging. Food Control. 2016;59:366-76.

100. Kohsari I, Shariatinia Z, Pourmortazavi SM. Antibacterial electrospun chitosanpolyethylene oxide nanocomposite mats containing bioactive silver nanoparticles. Carbohydrate polymers. 2016;140:287-98. 
101. Jin S, Li J, Wang J, Jiang J, Zuo Y, Li Y, et al. electrospun silver ion-loaded calcium phosphate/chitosan antibacterial composite fibrous membranes for guided bone regeneration. International journal of nanomedicine. 2018;13:4591.

102. Dhurai B, Saraswathy N, Maheswaran R, Sethupathi P, Vanitha P, Vigneshwaran S, et al. Electrospinning of curcumin loaded chitosan/poly (lactic acid) nanofilm and evaluation of its medicinal characteristics. Frontiers of Materials Science. 2013;7(4):350-61.

103. Charernsriwilaiwat N, Opanasopit P, Rojanarata T, Ngawhirunpat T. Lysozyme-loaded, electrospun chitosan-based nanofiber mats for wound healing. International Journal of Pharmaceutics. 2012;427(2):379-84.

104. Kong L, Ziegler GR. Role of molecular entanglements in starch fiber formation by electrospinning. 2012;13(8):2247-53.

105. Aydogdu A, Sumnu G, Sahin S. A novel electrospun hydroxypropyl methylcellulose/polyethylene oxide blend nanofibers: Morphology and physicochemical properties. Carbohydrate polymers. 2018;181:234-46.

106. Nie H, He A, Zheng J, Xu S, Li J, Han CC. Effects of chain conformation and entanglement on the electrospinning of pure alginate. Biomacromolecules. 2008;9(5):1362-5.

107. Bonino CA, Krebs MD, Saquing CD, Jeong SI, Shearer KL, Alsberg E, et al. Electrospinning alginate-based nanofibers: From blends to crosslinked low molecular weight alginate-only systems. Carbohydrate Polymers. 2011;85(1):111-9.

108. Reddy N, Yang Y. Innovative bio bers from renewable resources: Springer; 2015.

109. Alborzi S, Lim L-T, Kakuda Y. Encapsulation of folic acid and its stability in sodium alginate-pectin-poly (ethylene oxide) electrospun fibres. Journal of microencapsulation. 2013;30(1):64-71.

110. Lindman B, Karlström G, Stigsson L. On the mechanism of dissolution of cellulose. Journal of Molecular Liquids. 2010;156(1):76-81.
111. Frey MW. Electrospinning cellulose and cellulose derivatives. Polymer Reviews. 2008;48(2):378-91.

112. Rezaei A, Nasirpour A, Fathi M. Application of cellulosic nanofibers in food science using electrospinning and its potential risk. Comprehensive Reviews in Food Science and Food Safety. 2015;14(3):269-84.

113. Huang X-J, Chen P-C, Huang F, Ou Y, Chen $\mathrm{M}-\mathrm{R}, \mathrm{Xu} \mathrm{Z}-\mathrm{K}$. Immobilization of Candida rugosa lipase on electrospun cellulose nanofiber membrane. Journal of Molecular Catalysis B: Enzymatic. 2011;70(3):95-100.

114. Wang X, Kim Y-G, Drew C, Ku B-C, Kumar J, Samuelson LA. Electrostatic assembly of conjugated polymer thin layers on electrospun nanofibrous membranes for biosensors. Nano Letters. 2004;4(2):331-4.

115. Unnithan AR, Barakat NA, Pichiah PT, Gnanasekaran G, Nirmala R, Cha Y-S, et al. Wound-dressing materials with antibacterial activity from electrospun polyurethane-dextran nanofiber mats containing ciprofloxacin $\mathrm{HCl}$. Carbohydrate polymers. 2012;90(4):1786-93.

116. Jiang H, Fang D, Hsiao BS, Chu B, Chen W. Optimization and characterization of dextran membranes prepared by electrospinning. Biomacromolecules. 2004;5(2):326-33.

117. Ritcharoen W, Thaiying Y, Saejeng Y, Jangchud I, Rangkupan R, Meechaisue C, et al. Electrospun dextran fibrous membranes. Cellulose. 2008;15(3):435-44.

118. Xu F, Weng B, Gilkerson R, Materon LA, Lozano $\mathrm{K}$. Development of tannic acid/chitosan/pullulan composite nanofibers from aqueous solution for potential applications as wound dressing. Carbohydrate polymers. 2015;115:16-24.

119. Islam MS, Akter N, Karim MR. Preparation of superhydrophobic membranes by electrospinning of fluorinated silane functionalized pullulan. Colloids and Surfaces A: Physicochemical and Engineering Aspects. 2010;362(1):117-20.

120. Fuenmayora CA, Mascheronia E, Cosioa MS, Piergiovannia L, Benedettia S, Ortenzic M, et al. Encapsulation of R-(+)-limonene in edible 
electrospun nanofibers. Chemical Engineering.

$2013 ; 32$

\section{How to cite:}

Aman Mohammadi M, Rostami M.R, Raeisi M, Tabibi Azar M. Production of Electrospun Nanofibers from Food Proteins and Polysaccharides and Their Applications in Food and Drug Sciences. Jorjani Biomedicine Journal. 2018; 6(4): 62-77.

77| Jorjani Biomedicine Journal. 2018; 6(4): P 62-77. 